Ann. Biol. anim. Bioch. Biophys., 1979, 19 (4 A), 1141-1146.

\title{
Histological testicular parameters in bilateral cryptorchid adult rams
}

par Marie-Thérèse HOCHEREAU-DE REVIERS, M. R. BLANC, Claire CAHOREAU, M. COUROT, J. L. DACHEUX*, Claudine PISSELET

Station de Physiologie de la Reproduction, I.N.R.A., Nouzilly, 37380 Monnaie.

* Faculté des Sciences, Laboratoire de Physiologie comparée, Parc de Grandmont, 37000 Tours.

Summary. Three male lambs were rendered bilaterally cryptorchid at 15 weeks of age. They were killed when adult during the sexual season in autumn and compared with 4 normal adult rams of the same age, slaughtered at the same time.

In the cryptorchid testes, there was a drastic decrease in the total number of Leydig cells per testis, in the length and diameter of seminiferous tubules, and in the numbers of stem spermatogonia. Sertoli cell numbers were normal.

The cryptorchid testis has been investigated mainly for the morphological appearance of the Leydig and Sertoli cells, the absence of differentiated germ cells, and the biochemical parameters of both infertubular and fubular tissues (see review of Van Demark and Free, 1970). No numerical analysis of Leydig and Sertoli cells has been reported. The aim of our work was to present these numerical data in the cryptorchid testis of the ram.

\section{Material and methods.}

Three lambs were rendered bilaterally cryptorchid when they were 15 weeks old, just after puberty. They were killed one year later during the sexual season (autumn) and compared with 4 normal adult rams killed during the same season. After slaughter the testes were weighed and fragments of each testis were fixed in Bouin-Hollande solution and treated as previcusly described (Hochereau de Reviers and Courot, 1978). The relative volumes of intertubular tissue (figs. 2, 3) and seminiferous tubules were determined with a 25 point ocular integrator (Hennig, 1957) on 20 fields for each testis. The relative proportion of Leydig cells in the intertubular tissue was determined by the same method on 20 fields of intertubular tissue for each 
testis. The total volumes of inferfubular tissue, Leydig cells and tubular tissue were then calculated from the testis volume and the relative volume of each element respectively. The diameter of the seminiferous tubules was measured with an ocular micrometer on 20 cross sections of tubules per testis. The cross sectional areas of the cytoplasm and nuclei of Leydig cells (figs 4,5 ) and that of the nuclei of Sertoli cells were estimated from camera lucida drawings of 20 cells per animal. From the estimation of Leydig cell volume, the total number of Leydig cells per testis was calculated. The Sertoli cells and type $A_{0}$ and $A_{1}$ spermatogonia of each animal (Hochereau-de Reviers, Ortavant and Courot, 1976) were counted in $10 \mu \mathrm{m}$-thick cross sections at stage 8 of Ortavant's classification (1958). The true numbers of these cells per cross section were calculated by the formula of Abercrombie (1946) as modified by Ortavant (1958). The total numbers of Sertoli cells and $A_{0}$ and $A_{1}$ spermatogonia per testis were determined as described by Attal and Courot (1963).

\section{Results.}

Cryptorchidism resulted in drastic decreases in testis weight $(\times 0.12$, fig. 1a), total volume of intertubular tissue per testis $(\times 0.18$, fig. $1 \mathrm{~b})$, and total volume of Leydig cells per testis $(\times 0.16$, fig. $1 c)$. However, the cytoplasmic and nuclear cross sectional
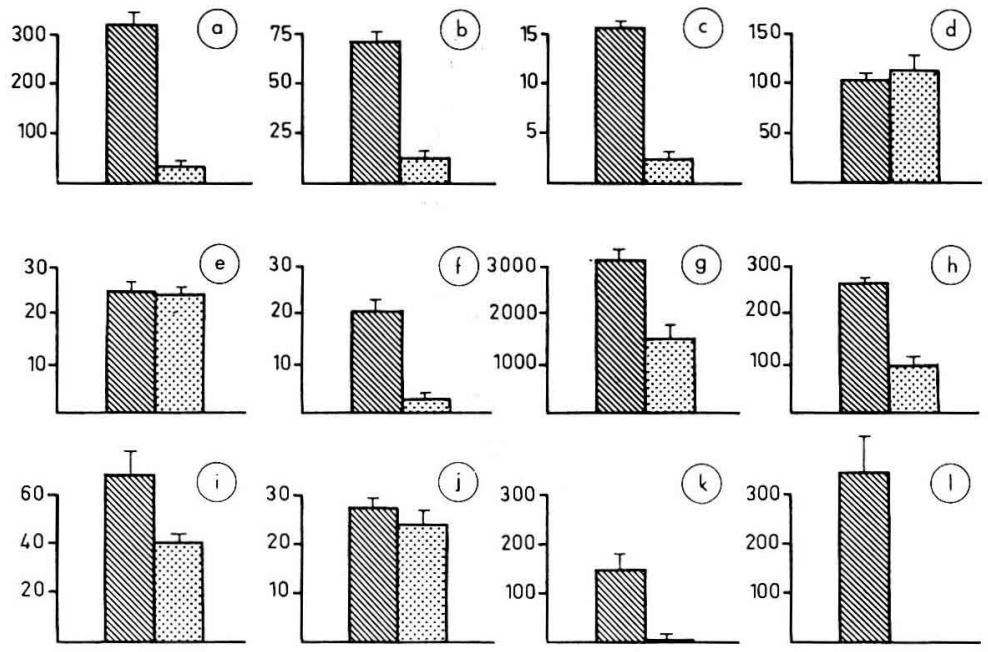

FIG. 1. - Comparisons of histological parameters in normal and cryptorchid testes of adult rams $\left(m \pm\right.$ s. e. $m$.). a) Testis weight $(g)$ b) Total volume of intertubular tissue per testis $\left(\mathrm{cm}^{3}\right)$;

c) Total volume of Leydig cells per testis $\left.\left(\mathrm{cm}^{3}\right) ; d\right)$ Leydig cells : individual cytoplasmic cross sectional area $\left(\mu \mathrm{m}^{2}\right)$; e) Leydig cells : individual nuclear cross sectional area $\left(\mu \mathrm{m}^{2}\right)$; $\left.f\right)$ Total number of Leydig cells per testis $\left.\left(\times 10^{8}\right) ; g\right)$ Total length of seminiferous tubules per testis $(\mathrm{m})$; h) Mean tubular diameter of seminiferous tubules $(\mu \mathrm{m})$; i) Sertoli cells : individual nuclear area $\left.\left(\mu \mathrm{m}^{2}\right) ; j\right)$ Total corrected number of Sertoli cells per testis $\left.\left(X 10^{8}\right) ; k\right)$ Tolal corrected number of $A_{0}$ reserve spermatogonia per festis $\left.\left(\times 10^{6}\right) ; l\right)$ Total corrected number of $A_{1}$ renewing spermatogonia per festis $\left(\times 10^{6}\right)$. 
areas of the Leydig cells were not modified by cryptorchidism (figs 1d, e, 4 and 5), and from these last data we deduced that the total number of Leydig cells per testis was greatly diminished by cryptorchidism ( $\times 0.14$, fig. $1 f$ ).

The total length of seminiferous fubules per testis and their mean diameter were reduced after cryptorchidism (respectively $\times 0.5$, fig. $1 \mathrm{~g}$ and $\times 0.4$, fig. $1 \mathrm{~h}$ ), The nuclear cross sectional area of Sertoli cells was decreased after cryptorchidism ( $\times 0.6$, fig. $1 i$ ), while their total number per testis was not significantly affected (fig. $1 j$ ).

$A_{0}$ reserve stem cells were scarcely observed in the tubules of adult cryptorchid rams (fig. 1k), while $A_{1}$ spermatogonia were never observed (fig. 1/).

\section{Discussion and conclusion.}

The decrease in testis weight of the ram after cryptorchidism resulted from depletion of both intertubular and tubular tissues.

The total volume of Leydig cells per testis was drastically reduced by cryptorchidism. A similar depletion was observed in unilateral cryptorchid pigs (Van Straaten and Wensing, 1977). Despite this, neither the area of Leydig cell cytoplasm nor that of the nuclei was affected, although changes were observed in the unilateral cryptorchid (Van Straaten and Wensing, 1977 ; Hochereau-de Reviers et al., unpublished - data). Cellular size of Leydig cells in normal and cryptorchid ram testes showed skewed distributions. Contrary to the bimodal distribution of these cells in the boar (Van Straaten and Wensing, 1977), the populations of Leydig cells in the ram were homogeneous. However, we formerly numbered and analysed only the morphologically active looking Leydig cells and possibly underestimated the values, as the precursors or the degenerated Leydig cells could not be identified. But to obtain an identical total volume of Leydig cells in normal and cryptorchid testes, it would be necessary for the totality of the cryptorchid intertubular tissue to be occupied by Leydig cells : in fact, there were also blood vessels, fibroblasts and peritubular cells. As a consequence of the decreased total volume and constant individual cellular volumes of Leydig cells, the total number of Leydig cells per testis was greatly reduced by cryptorchidism. This decrease in Leydig cell numbers could be due to blockage of Leydig cell mitoses by elevated temperature, to a non-differentiation of Leydig cells from their precursors, or to degeneration of Leydig cells formed before the animals were rendered cryptorchid. Despite these decreased numbers, the plasma levels of testosterone in the peripheral blood (Cahoreau et al., 1979) were equivalent to that of normal rams at the same season (Garnier et al., 1978). This may be related to increased steroid synthesis by these Leydig cells, since androgen concentrations in the interstitial fluid of the cryptorchid testis were higher than those in normal testes (Hagenäs et al., 1978a) due to the enhancement of steroid biosynthesis by elevated temperature (Gospodarowicz and Legault-Démare, 1962).

The depletion of the total volume of seminiferous tubules per festis was due to a decrease in both the length and the diameter of the seminiferous tubules. This resulted in a diminution in the surface of the basal lamina of the seminiferous tubules, possibly correlated with qualitative changes in it. Hadziselimovic and Seguchi (1973) observed an increase in collagen in the peritubular cells and a thickening of the basal membrane 
in cryptorchid testes of the human infant. The total number of Sertoli cells per testis was not affected by cryptorchidism in the present experiment which was performed at an age (15 weeks) when supporting cell division has definitively stopped (Courot, 1971). In another group of animals where unilateral cryplorchidism has been induced earlier in life, when the lambs were 6 weeks old, the total number of Sertoli cells per testis was diminished (Blanc ef al., 1977). The cross sectional nuclear area of Sertoli cells was decreased by cryptorchidism. In such animals the mean plasma levels of FSH were significantly elevated, compared with that of normal animals (Blanc et al., 1978), as were the interstitial fluid FSH levels (Hagenäs et al., 1978b) ; despite this, FSH receptors in the cryptorchid Sertoli cells were greatly reduced as compared to those of the normal rat testis (Hagenäs ef al., 1978a). The elevation of plasma FSH levels would result from an absence of secretion of inhibin in the presence of normal testosterone plasma levels (Blanc et al., 1978). Secretion of œstrogens was reported to be normal or decreased in cryptorchid animals (Liptrap and Raeside, 1970 ; Abney ef al., 1977).

In the adult cryptorchid ram few $A_{0}$ and $A_{1}$ spermatogonia were present in the abdominal testis, while gonocytes have been shown to divide in the abdominal fœial testis at the same temperature (Courot, 1971). This could be due to the high sensitivity of differentiated germ cells to elevated temperatures in the ram (Waites and Ortavant, 1968).

In conclusion, the total number of Leydig cells per testis is drastically reduced while their androgen secretion is enhanced. The total number of Sertoli cells per testis is not modified. Although cryptorchidism occurred after cessation of supporting cell mitoses, secretion of inhibin is drastically depressed (Blanc, et al., 1978). In adult rams, most of the stem cells had degenerated after cryptochidism, despife the fact it occurred late during the life.

Reçu en janvier 1979.

Acceplé en avril 1979.

Acknowledgments. - The skilled technical assistance of Mrs. Christine Perreau and Mr. J. C. Poirier is acknowledged. This work was supported by DGRST, grant No. 76-7-0047. The authors thank Dr. Meredith Lemon for her help in preparing the manuscript in English.

Résumé. Trois agneaux Préalpes âgés de 15 semaines ont été rendus bilatéralement cryptorchides. Ils ont été abattus à l'âge adulte durant la saison sexuelle (automne) ef comparés à 4 béliers adultes normaux castrés au même âge et à la même saison.

Dans les testicules des béliers cryptorchides, on a observé une diminution très importante du nombre total de cellules de Leydig par testicule, du diamètre et de la longueur des tubes séminifères et des spermatogonies souches alors que le nombre de cellules de Sertoli est maintenu normal.

FIGS. 2, 3. - Microscopic appearance $(\times 200)$ of cryptorchid (2) and normal (3) testes : interfubular tissue; 8 seminiferous tubules.

FIGS. 4, 5. - Microscopic appearance $(\times 1000)$ of intertubular tissue in cryptorchid (4) and normal (5) festes : The drawing shows the nuclear and cytoplasmic limits of a cross-sectioned Leydig cell 


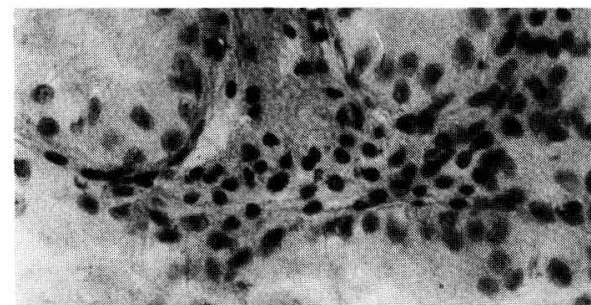

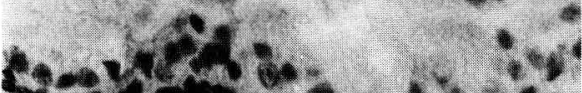

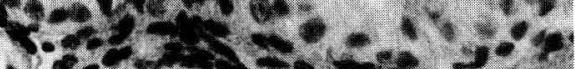

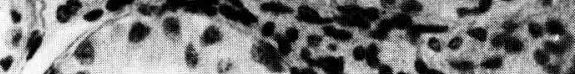

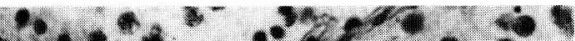

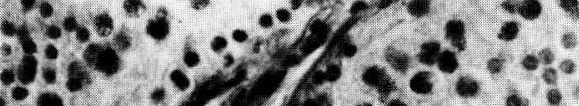

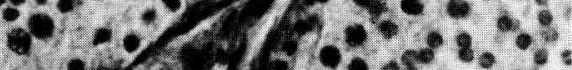

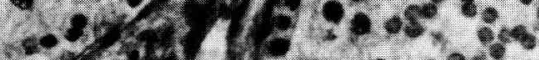

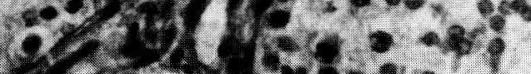

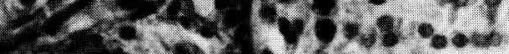

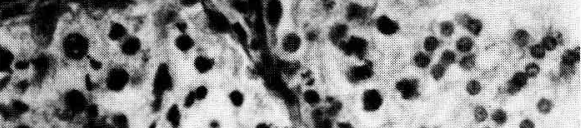

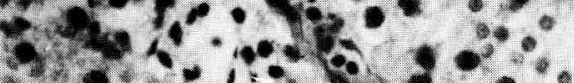
Ki
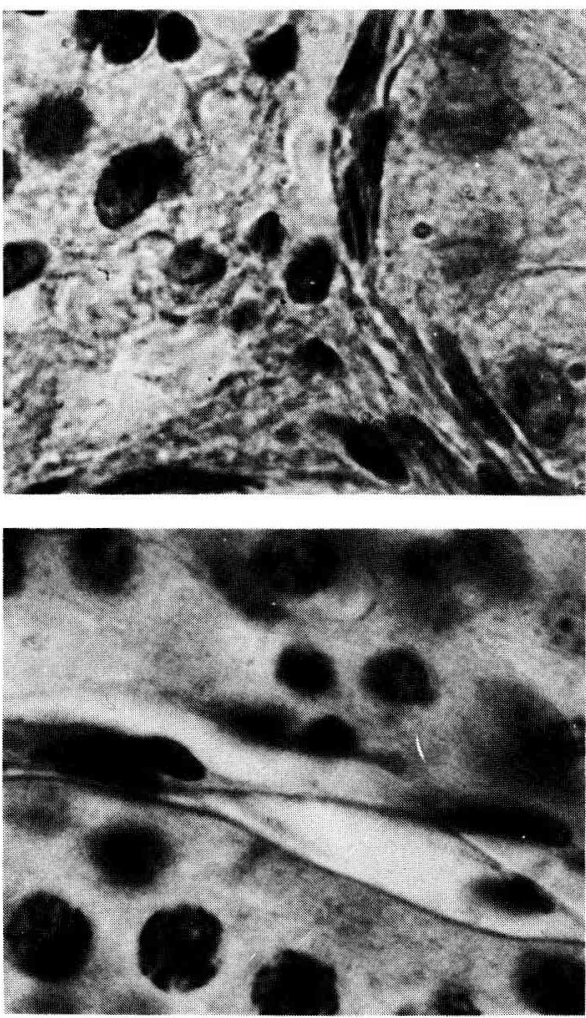

3
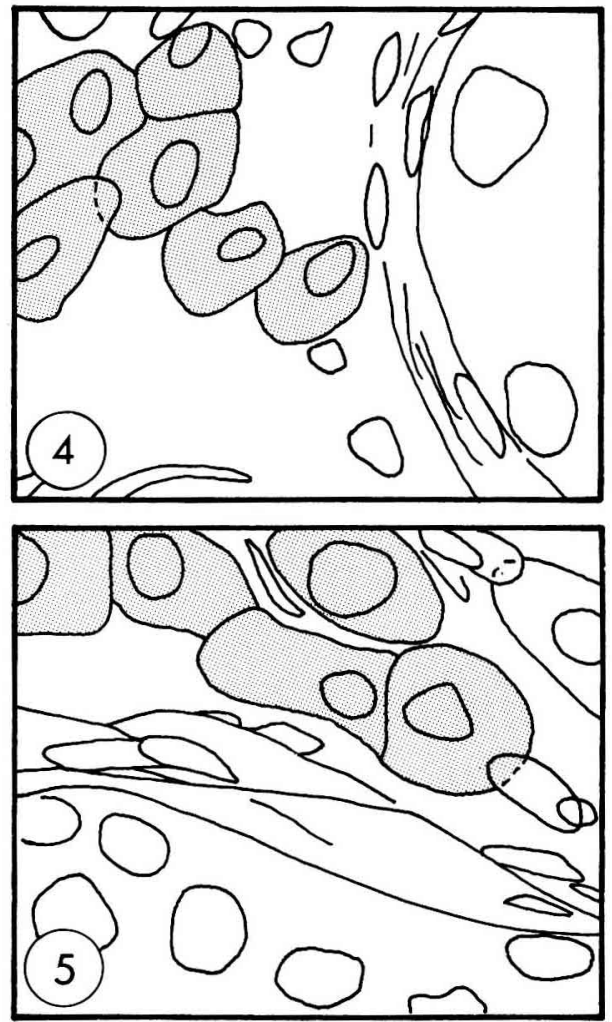


\section{References}

ABERCROMBIE M., 1946. Estimation of nuclear population from microtome sections. Anat. Rec., 94, 238-248.

ABNEY T. O., GRIER H., MAHESH V. B., 1977. Estradiol binding capacity in the cryptorchid rat testis Endocrinology, 101, 975-983.

ATTAL J., COUROT M., 1963. Développement testiculaire et établissement de la spermatogenèse chez le taureau. Ann. Biol. anim. Bioch. Biophys., 3, 219-241.

BLANC M. R., COUROT M., HOCHEREAU-de REVIERS M. T., POIRIER J. C., 1977 . Effet de l'hémicastration ou de l'hémicryptorchidie, pratiquées chez l'agneau impubère sur les taux de FSH plasmatiques ef sur les testicules restants. J. Physiol., Paris, 73, $91 \mathrm{~A}$.

BLANC M. R., CAHOREAU C., COUROT M., DACHEUX J. L., HOCHEREAU-de REVIERS M. T.,. PISSELET C, 1978. Plasma follicle stimulating hormone (FSH) and luteinizing hormone (LH) suppression in the cryptorchid ram by a non steroid factor (inhibin) from ram rete testis fluid. Int. J. Androl., Suppl. 2, 139-146.

CAHOREAU C., BLANC M. R., DACHEUX J. L., PISSELET C., COUROT M., 1979. Inhibin activity in ram rete testis fluid : depression of plasma follitropin (FSH) and lutropin (LH) in the castrate and cryptorchid ram. J. Reprod. Fert. Suppl. 26, (in press).

COUROT M., 1971. Etablissement de la spermatogenèse chez l'agneau (ovis aries). Efude expérimentale de son contrôle gonadotrope : importance de la lignée sertolienne. Thèse Doct. ès Sci. nat., Paris, CNRS n ${ }^{\circ} 6317$.

GARNIER D. H., COTTA Y., TERQUI M., 1978. Androgen radioimmunoassay in the ram : results of direct plasma testosterone and dehydroepiandrosterone measurement and physiological evaluation. Ann. Biol. anim. Bioch. Biophys., 18, 265-281.

GOSPODAROWICZ D., LEGAULT-DÉMARE J., 1962. Influence de la température d'incubation sur la synthèse in vitro de certains stéroïdes dans le testicule de rat. C. R. Acad. Sci. Paris, Sér. D, 255, 3047-3049.

HADZISELIMOVIC F., SEGUCHI H., 1973. Elektronen mikroskopische Untersuchungen beim Kryptorchismes. Z. Kinderchir., 12, 376-381.

HAGENÄS L., RITZEN E. M., SVENSSON J., HANSSON V., PURVIS K., 1978a. Temperature dependence of Sertoli cell function. Int. J. Androl., Suppl. 2, 449-459.

HAGENÄS L., RITZEN E. M., SUGINAMI M., 1978b. Hormonal milieu of the seminiferous tubules in the normal and cryptorchid rat. Int. J. Androl. 1, 477-484.

HENNIG A., 1957. Das Problem der Kernmessung. Eine Zusammenfessung und Erweiterung der mikroskopischen Messtechnik. Mikroskopie, 12, 174-203.

HOCHEREAU-de REVIERS M. T., COUROT M., 1978. Sertoli cells and development of seminiferous epithelium. Ann. Biol. anim. Bioch. Biophys., 18, 573-583.

HOCHEREAU-de REVIERS M. T., ORTAVANT R., COUROT M., 1976. Type A spermatogonia in the ram. In Sperm action. HUBINONT P. O., L'HERMITE M., Progr. Reprod. Biol., Vol. 1, 13-19, S. Karger Publ., Basel.

LIPTRAP R. M., RAESIDE J. I., 1970. Urinary steroid excretion in cryptorchidism in the pig. J. Reprod. Fert., 21, 293-301.

ORTAVANT R., 1958 . Le cycle spermatogénétique chez le bélier. Thèse Doct. ès Sci. nat., Paris, CNRS, $n^{\circ}$ A 3118-0-3990.

VAN DEMARK N. L., FREE M. J., 1970. Temperature effects. In JOHNSON A. D., GOMEZ W. R., VAN DEMARK N. L. The festis, Vol. III, 233-312, Acad. Press.

VAN STRAATEN H. W. M., WENSING C. J. G., 1977. Histomorphometric aspects of testicular morphogenesis in the naturally unilateral cryptorchid pig. Biol. Reprod., 17, 473-479.

WAITES G. M. H., ORTAVANT R., 1968. Effets précoces d'une brève élévation de la température testiculaire sur la spermatogenèse du bélier. Ann. Biol. anim. Bioch. Biophys., 8, 323-331. 